\title{
ПОЛИМОРФИЗМ ГЕНА АGТ (RS699) И ПРОФЕССИОНАЛЬНАЯ СПОРТИВНАЯ УСПЕШНОСТЬ (ОБЗОР)
}

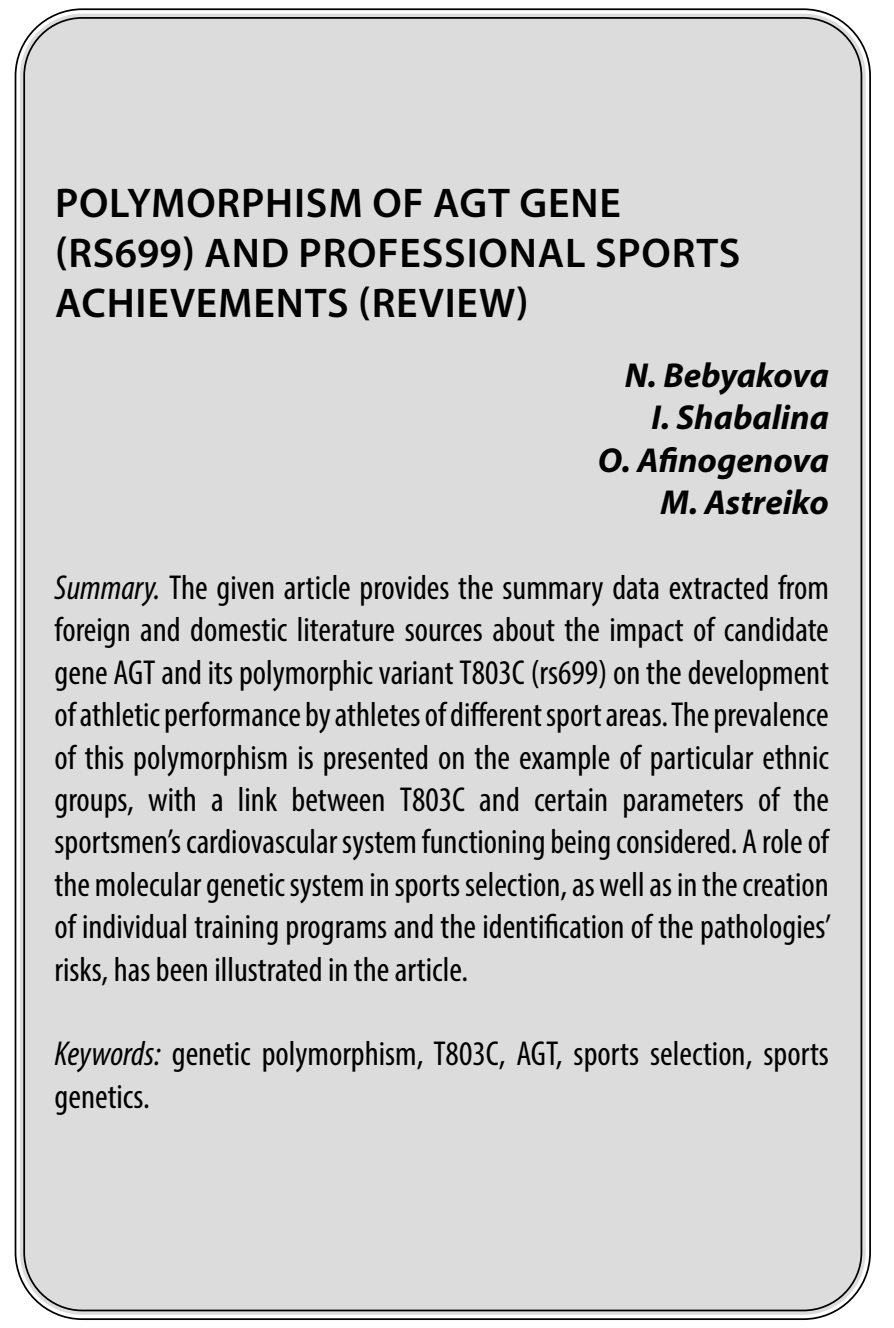

B ажнейшим направлением современной спортивной медицины является эффективный отбор молодых людей, перспективных по своим наследственным качествам для занятия определенным видом спорта при минимальном риске для их здоровья.

В настоящее время известно, что генетические особенности организма могут влиять как на проявление выносливости (кардиореспираторной и/или мышечной), скоростно-силовые качества спортсмена (быстроту, взрывную или абсолютную силу), тренируемость, степень развития мускулатуры, так и на ограничение физической деятельности (риск развития сердечной патологии: в частности, гипертрофии миокарда левого желудочка, сердечной недостаточности, аритмий; а также заболеваний опорно-двигательной системы).
Бебякова Наталья Александровна Д.б.н., профессор, Северный государственный медицинский университет (2. Архангельск) nbebyakova@mail.ru

Шабалина Ирина Алексеевна К.б.н., дочент, Северный государственный медицинский университет (2. Архангельск)

ira_sha@mail.ru

Афиногенова Оксана Анатольевна Северный государственный медицинский университет (2. Архангельск) oksana.afinogenova.97@yandex.ru Астрейко Мария Олеговна Северный государственный медицинский университет (2. Архангельск) astreiko.mo@gmail.com

Аннотация. В статье представлены обобщенные данные зарубежной и отечественной литературы 0 влиянии гена-кандидата AGT и его полиморфного варианта Т803C (rs699) на развитие высоких спортивных результатов у спортсменов различной специализации. Представлена распространенность данного полиморфизма в определенных этносах. Рассмотрена взаимосвязь полиморфизма Т803С с отдельными параметрами функционирования сердечно-сосудистой системы спортсменов. Показана роль молекулярно-генетического тестирования в спортивном отборе, индивидуализации тренировочного процесса и выявлении рисков профессиональных спортивных патологий.

Ключевые слова: генетический полиморфизм, Т803С, АGT, спортивный отбор, спортивная генетика.

Наследственные факторы формирования мышечной массы определяют предрасположенность к определенному типу физической нагрузки. Так, анализ генетических особенностей организма позволяет оценить степень предрасположенности индивида к занятиям спортом в целом и конкретно к различным спортивным направлениям, что может быть использовано для большей рационализации отбора тренерами потенциально перспективных кандидатов.

Результаты молекулярно-генетического тестирования спортсменов позволяют оптимизировать тренировочный процесс за счёт подбора индивидуального режима и интенсивности нагрузки. С помощью генетического теста легче разработать эффективный подход к восстановлению формы спортсмена после тренировок 
и соревнований, а также определить риск развития возможных осложнений и неблагоприятных последствий для здоровья.

Таким образом, анализ генетических маркёров, определяющих предрасположенность к физической активности, является достаточно актуальным. Данный обзор посвящен одному из изучаемых «спортивных полиморфизмов» - полиморфизму rs699 гена ангиотезиногена (AGT).

Ренин-ангиотензиновая система (РАC) играет важную роль в регуляции артериального давления. Одним из ключевых генов РАС является ген ангиотензиногена, расположенный в большом плече 1 хромосомы. В данном гене выявлено более 40 однонуклеотидных полиморфизмов. Одним из наиболее исследуемых является полиморфизм Т803С, связанный с заменой тимина (Т) на цитозин (С) в 803-м положении гена, с соответствующей заменой метионина на треонин в белке (М268T). Данный полиморфизм находится во втором экзоне гена AGT, повышает уровень его экспрессии и приводит к активации ренин-ангиотензиновой системы. Известна взаимосвязь данного аллельного варианта с риском развития артериальной гипертензии и ряда других патологий сердечно-сосудистой системы [12]. По мнению некоторых авторов, rs699 связан с повышенным риском избыточной массы тела [9].

Ген AGT находится в локусе 1q42-q43, содержит 5 экзонов и кодирует синтез ангиотензиногена, который является сывороточным белком а-глобулиновой фракции, с молекулярной массой около 65 кДа. Ангиотензиноген синтезируется главным образом печенью и адипоцитами жировой ткани. Синтез данного белка находится под контролем эстрогенов, глюкокортикоидов, тиреоидных гормонов. Превращение ангиотензиногена в неактивный ангиотензин-І происходит при участии протеолитического фермента ренина. Под действием ангиотензинпревращающего фермента и ряда альтернативных путей с участием химаз, катепсина $G$, тонина и других сериновых протеаз, ангиотензин-І преобразуется в биологически активное вещество ангиотензин-II, который реализует свой эффект через ангиотензиновые рецепторы $[4,11]$.

К настоящему времени установлено, что ангиотензины являются биопептидами с широким физиологическим спектром действия. Они регулируют уровень артериального давления и почечную фильтрацию, водно-солевой баланс; участвуют в регуляции стрессорных реакций. Ангиотензины способны воздействовать на гладкомышечные клетки сосудистой стенки, вызывая вазоконстрикторный эффект. Известно влияние данных биопептидов на эндотелий сосудов и последующее из- менение продукции оксида азота (NO) и эндотелинов. B современной литературе описывается воздействие ангиотензинов на миокард, приводящее к усилению его сокращения [1]. В частности, аллель C гена AGT коррелирует с повышенным кровяным давлением в покое или в ответ на интенсивные физические нагрузки, а также с увеличением доли быстро сокращающихся мышечных волокон [3].

В настоящее время генетические исследования ренин-ангиотензиновой системы в отношении спортивных результатов или статуса спортсмена в основном сосредоточены на гене ангиотензинпревращающего фермента (АСЕ) и его инсерционном / делеционном полиморфизме. Однако интересно также и изучение второго по значимости гена РАС, а именно функционального полиморфизма rs699 (М268T) в гене ангиотензиногена (AGT), на предмет ассоциации со спортивным статусом и уровнем физической работоспособности.

Отмечены этнические особенности распространенности полиморфизма Т803С. Так в популяциях Европы частота аллеля 803С колеблется от 0,250 до 0,690, в то время как в азиатских популяциях аллель С встречается в интервале от 0,174 до 0,950, а в африканских от 0,475 до 1,000 (The Al.lete FREquency Database; http:// alfred.med.yale.edu).

В научной литературе существуют данные о том, что полиморфизм rs699 гена AGT связан со статусом силового спортсмена, но не спортсмена, тренирующего выносливость. Приводятся данные о достоверном различии распределения генотипов и аллелей полиморфизма Т803С между спортсменами-силовиками и выносливыми спортсменами, а также между спортсменами-силовиками и лицами контрольной группы. Отмечено, что частота генотипа СС (гомозиготы по мутантному аллелю) в группе силовых спортсменов примерно в 2,2 раза выше, чем в контрольной группе и в 3,1 раза выше, чем в группе выносливости. Наибольшая частота встречаемости аллеля С также выявлена в группе силовых спортсменов, по сравнению с группой контроля и группой выносливости. Отметим, что у спортсменов силовых видов спорта преобладает анаэробная выработка энергии, в отличие от спортсменов, тренирующих выносливость, для которых характерна в большей степени аэробная энергетическая продукция. Авторы связывают значительную распространенность генотипа СС среди силовых спортсменов с его благоприятным влиянием на наращивание мышечной массы [14]. Данный факт подтверждается и другими исследованиями $[6,8]$.

В мировых исследованиях в области спортивной генетики выявлено, что некоторые генетические полиморфизмы связаны с элитной силой и спринтерской произ- 
водительностью, и нынешняя парадигма заключается в том, что элитная производительность является полигенным признаком, с незначительным вкладом каждого варианта в уникальный спортивный фенотип. Отмечено, что полиморфизм гена AGT (rs699) имеет связь с элитными энергетическими характеристиками спортсменов; однако результаты для данного гена менее последовательны, чем, например, для гена а-актинина-3 и его полиморфного варианта R577X [5].

Взаимосвязь однонуклеотидного полиморфизма гена AGT (rs699) с результатами спринтерских тестов приводится в общегеномном ассоциативном исследовании спринтерской производительности элитных юношеских футболистов с различными генетическими полиморфизмами [10].

По результатам нескольких последних мета-анализов, включающих исследование ДНК 5834 силовых атлетов и 14018 лиц контрольной группы, обнаружена значимая ассоциация полиморфизма rs699 в гене AGT со статусом силового спортсмена [13].

При анализе генетических маркёров физической работоспособности и их взаимосвязи с электрокардиографическими показателями у спортсменов юношеской лиги, выявлены отрицательные корреляции между величиной угла а в параметрах ЭКГ и генетическим полиморфизмом AGT (rs699). Этот факт свидетельствует о влиянии рецессивных гомозигот данного гена на величину указанного электрокардиографического показателя [2].
Эти данные согласуются с тем, что полиморфизм AGT (rs699) связан с массой левого желудочка сердца независимо от уровня артериального давления у обоих полов. При этом гомозиготы СС имеют большую массу левого желудочка по сравнению с гомозиготами ТТ как среди мужчин, так и среди женщин. Масса левого желудочка у гетерозигот ТС сопоставима с таковой у гомозигот ТТ среди женщин и гомозигот СС среди мужчин. Следовательно, можно сделать вывод о том, что половые гормоны могут влиять на рост миокарда по-разному, в зависимости от количества Т-аллелей, которые несет индивид. В исследовании, проведенном J Karjalainen (1999), показано, что сильный физиологический стимул к росту миокарда вызывает среднее увеличение массы ЛЖ на 50\% у мужчин и 53\% у женщин-спортсменов по сравнению с лицами контрольной группы соответствующей возрастной категории [7].

Стоит отметить, что исследования генетики спортивных результатов часто ограничены небольшим объемом выборки в отдельных исследованиях, а также неоднородностью исследуемых групп, нередко включающих спортсменов различных спортивных дисциплин. Большие, однородные, строго определенные выборки спортсменов, набранные посредством многонационального сотрудничества, помогут в проведении научных исследований генетических спортивных ассоциаций в масштабах всего генома. Такой подход позволит объективно идентифицировать потенциальные гены, влияющие на спортивные результаты, а значит быть определяющими для поиска кандидатов в соответствующие виды спорта.

\section{ЛИТЕРАТУРА}

1. Муженя Д. В. Патофизиологическая роль и прогностическая значимость М235T полиморфизма гена ангиотензиногена (AGT) при болезнях сердечного континуума (БСК) // Вестн. Адыгейского гос. ун-та. Сер. 4: Естеств.-матем. и техн. науки. 2011. № 3. С. 69-81.

2. Ярышева В. Б., Шибкова Д. З. Генетические предикторы адаптации сердечно-сосудистой системы подростков к физическим нагрузкам // Казанский медицинский журнал. 2017. Т. 98. № 1. С. 63-66.

3. Aleksandra Z, Zbigniew J, Waldemar M, et al. The AGT Gene M235T Polymorphism and Response of Power-Related Variables to Aerobic Training. Journal of Sports Science \& Medicine. 2016 Dec; 15(4):616-624.

4. Azizi M., Hallouin M.-C., Jeunemaitre X., Guyene T. T., Ménard J. Influence of the M235T Polymorphism of Human Angiotensinogen (AGT) on Plasma AGT and Renin Concentrations After Ethinylestradiol Administration // J. Clin. Endocrinol. Metab. 2000. Vol. 85, № 11. P. 4331-4337.

5. Eynon N., Hanson E. D., Lucia A., Houweling P. J., Garton F., North K. N., Bishop D. J. Genes for elite power and sprint performance: ACTN3 leads the way. Sport. Med. 2013; 43:803-817. doi: 10.1007/s40279-013-0059-4.

6. Gomez-Gallego F, Santiago C, González-Freire M, Yvert T, Muniesa CA, Serratosa L, Altmäe S, Ruiz JR, Lucia A. The C allele of the AGT Met235Thr polymorphism is associated with power sports performance. Appl Physiol Nutr Metab. 2009 Dec; 34(6):1108-11. doi: 10.1139/H09-108. PMID: 20029521.

7. Karjalainen J, Kujala UM, Stolt A, Mäntysaari M, Viitasalo M, Kainulainen K, Kontula K. Angiotensinogen gene M235T polymorphism predicts left ventricular hypertrophy in endurance athletes. J Am Coll Cardiol. 1999 Aug; 34(2):494-9. doi: 10.1016/s0735-1097(99)00199-0. PMID: 10440164.

8. Miyamoto-Mikami E, Murakami H, Tsuchie H, Takahashi H, Ohiwa N, Miyachi M, Kawahara T, Fuku N. Lack of association between genotype score and sprint/power performance in the Japanese population. J Sci Med Sport. 2017 Jan; 20(1):98-103. doi: 10.1016/j.jsams.2016.06.005. Epub 2016 Jun 23. PMID: 27380726.

9. Muñoz AM, Velásquez CM, Agudelo GM, et al. Examining for an association between candidate gene polymorphisms in the metabolic syndrome components on excess weight and adiposity measures in youth: a cross-sectional study. Genes \& Nutrition. 2017; 12:19. D0I: 10.1186/s12263-017-0567-1.

10. Pickering C, Suraci B, Semenova EA, et al. A genome-wide association study of sprint performance in elite youth football players. J Strength Cond Res. 2019; 33:2344-2351. 
11. Procopciuc L., Popescu T., Jebeleanu G., Pop D., Zdrenghea D. Essential Arterial Hypertesion and Polymorphism of Angiotensinogen M235T Gene // J. Cell. Mol. Med. 2002. Vol. 6, № 2. P. 245-250.

12. Sethi A.A., Nordestgaard B. G., Gronholdt M. L., Steffensen R., Jensen G., Tybjærg-Hansen A. Angiotensinogen Single Nucleotide Polymorphisms, Elevated Blood Pressure, and Risk of Cardiovascular Disease // Hypertension. 2003. Vol. 41, № 6. P. 1202-1211.

13. Weyerstra B, Jan et al. Nine genetic polymorphisms associated with power athlete status — A Meta-Analysis. J Sci Med Sport. 2018; 21(2):213-220.

14. Zarebska A, Sawczyn S, Kaczmarczyk M, Ficek K, Maciejewska-Karlowska A, Sawczuk M, et al. Association of rs699 (M235T) polymorphism in the AGT gene with power but not endurance athlete status. J Strength Cond Res. 2013; 27: 2898-2903. https://doi.org/10.1519/JSC.0b013e31828155b5 PMID: 23287839.

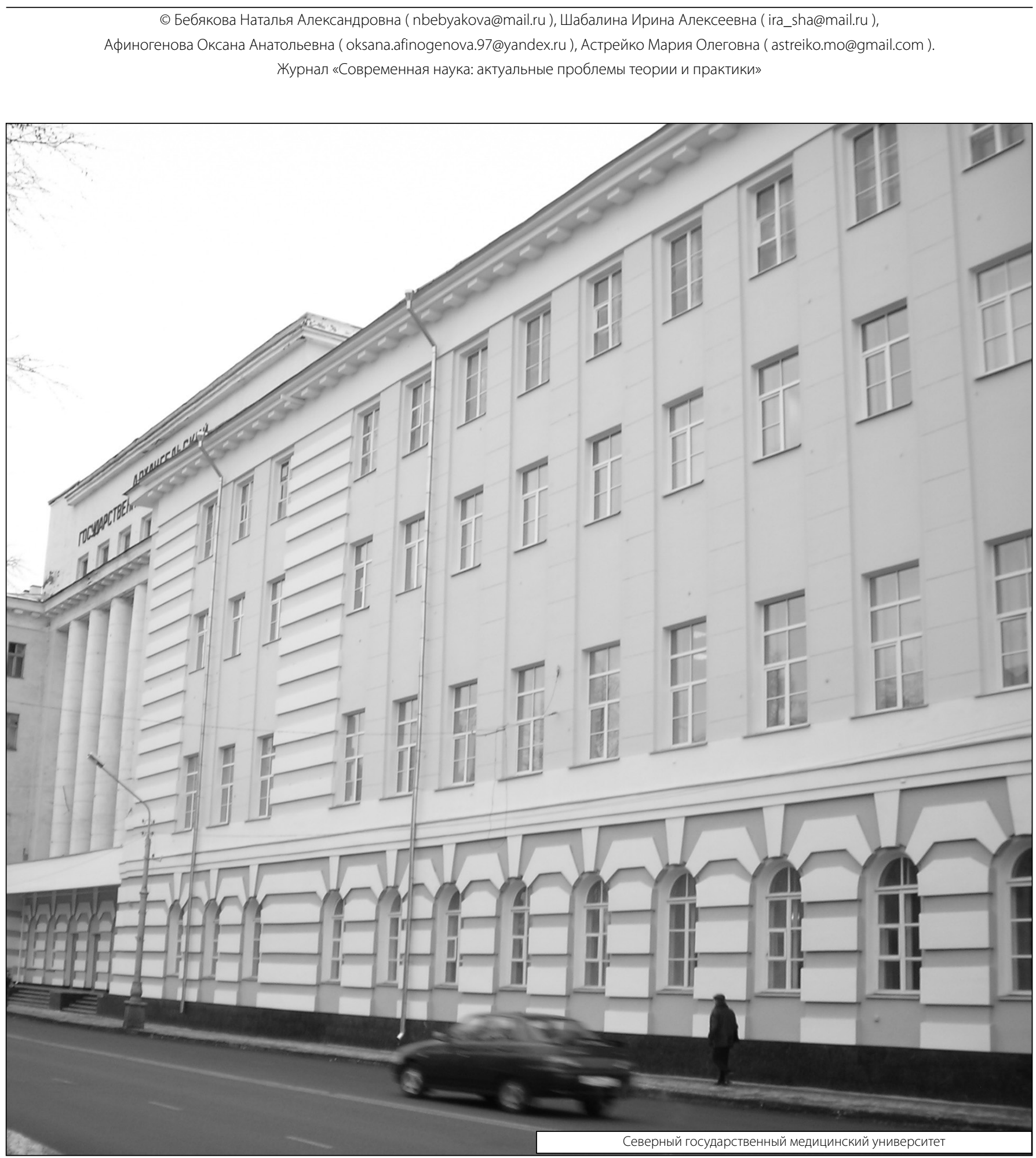

